\title{
Socioeconomic Performance in Sub-Saharan Africa with Reference to Southeast Asia: Natural Resources or Institutions?
}

\author{
Ben Katoka* and Huck-ju Kwon**
}

\begin{abstract}
This paper explores the relationship between institutional quality, dependence on natural resources, and socioeconomic performance in SubSaharan Africa (SSA) and Southeast Asia (SEA) in the period from 1995 to 2015. It uses three measures - per capita GDP growth; foreign direct investment inflows (FDI); and infant mortality rate - to capture socioeconomic performance. The World Bank's Regulatory Quality (RQ) indicator and the share of natural resource exports in percentage of total merchandise exports are used to capture institutional quality and resource dependence, respectively. Using Pooled OLS with robust estimators that control for temporal and spatial dependence, the paper finds that (1) higher levels of natural resource exports in SSA were significantly associated with larger FDI flows, but had no significant correlation with per capita GDP growth and infant mortality rate. Additionally, (2) in both SSA and SEA, a higher RQ score was significantly associated with increased per capita GDP growth and decreased infant mortality. The paper concludes by highlighting a few key areas that need serious consideration for further research on institutions and development in SSA.
\end{abstract}

Keywords: Sub-Saharan Africa, Southeast Asia, Regulatory Quality, resource dependence, socioeconomic performance.

\section{INTRODUCTION}

This paper aims at exploring the roles of institutional quality and dependence on natural resources in explaining socioeconomic performance in Sub-Saharan Africa

\footnotetext{
* Ph.D. in Public Policy (Seoul National University). Research Interests: governance, foreign direct investment policy, state fragility, and development in Sub-Saharan Africa and Southeast Asia. Corresponding author. E-mail: benkatoka@gmail.com.

** Professor (Graduate School of Public Administration, Seoul National University). E-mail: hkwon4@snu.ac.kr.
}

Manuscript received June 9, 2017; out for review June 19, 2017; review completed November 24, 2017; accepted November 27, 2017.

The Korean Journal of Policy Studies, Vol. 32, No. 3 (2017), pp. 1-27.

(C) 2017 by the GSPA, Seoul National University 
(SSA) and Southeast Asia (SEA) in the period from 1995 to 2015. The focus on SSA and SEA is motivated by recent increasing interest in understanding differences in development processes and outcomes between the two regions (see, i.e., Henley, 2015; Kelsall, 2013; Berendsen et al., 2013). Existing studies highlight that countries in both SSA and SEA are not fundamentally different in terms of their institutional landscape - populated by corrupt and non-democratic governments-but diverge widely in their development outcomes. However, a search of the literature revealed no empirical investigations of the impact of two major factors - institutional quality and dependence on natural resources - on economic and social outcomes in the two regions. Existing studies are generally narrative or based on comparative case studies.

The paper uses Pooled OLS estimators that control for temporal and spatial dependence (Driscoll and Kraay, 1998; Hoechle, 2007). It applies three sorts of performance measures, including GDP per capita growth, foreign direct investment (FDI), and one aspect of social welfare, namely the infant mortality rate. It draws on three analytical perspectives: first, the institutional perspective, which emphasizes institutions as the fundamental cause of good development performance (Acemoglu et al., 2005; Rodrik et al., 2004); second, the resource curse perspective, according to which abundance in natural resources adversely affects economic performance (Sachs and Warner, 1995)1; finally, the geographical perspective, which links development problems to physical or geographic causes such as the distribution of inland waterways and coastlines, and endemic diseases (Collier and Gunning, 1999; Gallup et al., 1999). In utilizing these three approaches, the paper aims to explain causalities between institutional quality, dependence on natural resources, and socioeconomic performance in the two regions. Additionally, the paper provides new insights into whether and how the effects of both institutional quality and natural resource dependence on socioeconomic performance are influenced by regional location-SSA or SEA.

The remaining part of the paper proceeds as follows: Section 2 explores existing research on development processes and outcomes in SSA and SEA. Section 3 provides a brief overview of cross-region and cross-country performance in a selection of economic, social, and institutional indicators. Section 4 describes the data and variables, and presents the hypotheses as well as the estimation model. Section 5 presents the estimation results and section 6 discusses their implications and concludes.

1. One should be aware of the debate with respect to measures of resource abundance or dependence (see, for example, Brunnschweiler 2008). 


\section{EXISTING STUDIES}

Efforts for understanding SSA development problems will often require understanding whether and how SSA responds differently to particular variables-i.e., economic, social, or institutional - compared to other developing regions. This explains the recent increasing amount of research that concentrates on SSA and SEA. As pointed out earlier, however, existing publications that contrast development processes and outcomes in SSA and SEA are generally narrative or based on comparative case studies.

For instance, Henley (2012) compares two countries in SEA (Indonesia and Malaysia) with two in SSA (Kenya and Nigeria) to explain the diverging development path between SEA and SSA. He argues that the differential performance between the two regions lies in pro-poor agricultural and rural development. He thus concludes that the first priority of SSA should be pro-poor agricultural development. Similarly, a pairwise comparative study of Indonesia and Nigeria and Malaysia and Kenya supports the idea of rural development as a key factor explaining divergent development trajectories between SSA and SEA (van Donge et al., 2012). Further, the study emphasizes the importance of macroeconomic stabilization and economic freedom for small entrepreneurs and peasant farmers in SEA.

One major study that explicitly focuses on an analysis of economic performance in the two regions is based on a series of comparative case studies of four SEA countries (Cambodia, Indonesia, Malaysia, and Vietnam) and four SSA countries (Kenya, Nigeria, Tanzania, and Uganda) (Berendsen et al., 2013). The study's main finding is that governance matters less than the content of policy in explaining the differential performance between the two regions. It thus concludes that "SSA does not need good governance before, and as a precondition for, development success" (p.500).

Similarly, Booth (2012) concludes that good governance, as advocated by western donors, should not be regarded as a prerequisite to economic development. His analysis is based on a series of case studies including Ethiopia, Ghana, Malawi, Mozambique, Rwanda, Tanzania, and Uganda, with certain references to SEA's experience. $\mathrm{He}$ argues that "in SSA, the most relevant dimension of variation among regimes is between more and less developmental forms of neopatrimonialism" (p. 25). Specifically, the most successful countries in SSA tend to have a combination of the following factors: (1) a strong and visionary leader, with centralized management of the main economic rents in support of a long-term vision; (2) a single or dominant party system; (3) a competent and confident economic technocracy; (4) consensual decision-making; and (5) a sound policy framework. In some of the successful countries such as Ethiopia and Rwanda, central leaderships have been able to pursue a national 
development vision and steer rent creation into areas with high economic potential. He further argues that neopatrimonial regimes have contributed to economic transformation in SEA countries such as Indonesia, Malaysia, and Vietnam.

Another major study examines variables that influence economic performance in ten high-growth performers in SSA (Cameroon, Cote d'Ivoire, Kenya, Malawi, and Mozambique) and SEA (Indonesia, Laos, Malaysia, Thailand, and Vietnam). The study concludes that inclusive institutions such as the rule of law, the absence of corruption, and property rights do not explain performance in the two regions (Kelsall, 2013). Instead, the study finds a combination of three factors to be the main determinants of good performance in SSA and SEA: (1) regulations that promote the private sector development, in particular foreign direct investment and industrial development; (2) resilience to external shocks; and (3) sound policy-making either through an effective bureaucracy insulated from political pressure or through a tradition of consensual decision-making and leadership succession.

Overall, all of the existing studies on development processes and outcomes in SSA and SEA countries tend to emphasize policy differences-not good governance-as the main explanation for the differential development performance between the two regions. The current study does not directly contradict these views, but seeks to examine the possibility that the differential socioeconomic performance reflects differences in institutional quality and dependence on natural resources. Additionally, the present paper goes beyond simple comparison of historical data and uses cross-sectional time series analytical tools to describe the role of institutional quality and natural resource dependence in the differential socioeconomic performance between SSA and SEA. The next section puts things in perspective by describing some of the major features of institutional quality, natural resource dependence, and socioeconomic performance in SSA and SEA.

\section{SOCIOECONOMIC PERFORMANCE IN SSA AND SEA: A BRIEF OVERVIEW}

To begin, Table 1 provides a brief comparison of some selected economic indicators for the two regions. In terms of GDP growth, for example, it shows that SEA consistently grew at an average of approximately 6.5 percent between 1995 and 2015. By contrast, SSA grew at an average of more than 3 percent per annum between 1995 and 2010, before declining to below 3 percent between 2010 and 2015. In per capita terms, the contrast between the two regions is even bigger. The table provides a simple comparison of mean and median per capita GDP adjusted for pur- 
chasing power parity (PPP) of the SEA countries compared with that of SSA countries. Medians are of interest due to the skewed nature of the observations resulting from the inclusion of countries like Brunei, Equatorial Guinea, or Mauritius. Further, Table 1 shows that in each period, income per capita in SSA has consistently remained about one-third that of SEA.

It is also useful to look at the ability of SEA and SSA countries to attract large inflows of FDI. It can be observed that SSA's performance in attracting FDI flows remained poor compared to SEA, even if the increase in the size of FDI flows to the region has been notable between 2000 and 2015 .

Table 1 also highlights the wide contrast in terms of social development between the two regions. For instance, performance in two major Millennium Development Goals (MDGs) - eradication of extreme poverty and hunger, and reduction of the under-five mortality rate by two-thirds between 1990 and 2015-has been widely satisfactory in SEA compared to SSA.

Table 1. Selected economic and social indicators in SSA and SEA (all incomes)

\begin{tabular}{|c|c|c|c|c|c|c|}
\hline & Region & 1995 & 2000 & 2005 & 2010 & 2015 \\
\hline $\begin{array}{l}\text { Mean GDP per Capita, } \\
\text { PPP (constant } 2011 \$ \text { ) }\end{array}$ & $\begin{array}{l}\text { SSA } \\
\text { SEA }\end{array}$ & $\begin{array}{c}2,217.53 \\
11,671.52\end{array}$ & $\begin{array}{l}2,787.348 \\
11,232.85\end{array}$ & $\begin{array}{c}3,902.8 \\
13,272.78\end{array}$ & $\begin{array}{c}4,769.48 \\
15,673.18\end{array}$ & $\begin{array}{c}5,609.60 \\
17,849.55\end{array}$ \\
\hline $\begin{array}{l}\text { Median GDP per } \\
\text { capita, PPP (constant } \\
2011 \$ \text { ) }\end{array}$ & $\begin{array}{l}\text { SSA } \\
\text { SEA }\end{array}$ & $\begin{array}{c}1,121.7 \\
3,654.98\end{array}$ & $\begin{array}{l}1,297.72 \\
3,400.54\end{array}$ & $\begin{array}{l}1,665.35 \\
4,305.77\end{array}$ & $\begin{array}{l}2,163.53 \\
5,550.36\end{array}$ & $\begin{array}{l}2,547.95 \\
7,282.27\end{array}$ \\
\hline $\begin{array}{l}\text { GDP, annual \% growth } \\
\text { rate }\end{array}$ & $\begin{array}{l}\text { SSA } \\
\text { SEA }\end{array}$ & $\begin{array}{l}4.96 \\
7.27\end{array}$ & $\begin{array}{l}3.70 \\
6.73\end{array}$ & $\begin{array}{l}5.50 \\
6.87\end{array}$ & $\begin{array}{l}3.66 \\
6.83\end{array}$ & $\begin{array}{l}2.89 \\
5.14\end{array}$ \\
\hline $\begin{array}{l}\text { Net inflows of FDI } \\
\text { (million USD) }\end{array}$ & $\begin{array}{l}\text { SSA } \\
\text { SEA }\end{array}$ & $\begin{array}{l}100.266 \\
1797.05\end{array}$ & $\begin{array}{l}150.386 \\
724.406\end{array}$ & $\begin{array}{c}432.668 \\
2767.728\end{array}$ & $\begin{array}{c}617.253 \\
5821.172\end{array}$ & $\begin{array}{c}908.411 \\
7188.107\end{array}$ \\
\hline $\begin{array}{l}\text { Proportion of people } \\
\text { living on less than } \\
\$ 1.25 \text { a day }\end{array}$ & $\begin{array}{l}\text { SSA } \\
\text { SEA }\end{array}$ & $\begin{array}{l}57 \\
46\end{array}$ & - & - & - & $\begin{array}{c}41 \\
7\end{array}$ \\
\hline $\begin{array}{l}\text { Under-five mortality } \\
\text { rate, deaths per } 1,000 \\
\text { live births }\end{array}$ & $\begin{array}{l}\text { SSA } \\
\text { SEA }\end{array}$ & $\begin{array}{l}179 \\
71\end{array}$ & - & - & - & $\begin{array}{l}86 \\
33\end{array}$ \\
\hline
\end{tabular}


Moreover, according to the 2015 Human Development Report of the United Nations Development Program (UNDP, 2015), twenty-seven of the thirty countries that rank lowest, and nineteen of the bottom twenty, are in SSA. Further, of the forty-five SSA countries included in the current analysis, thirty-seven are in the bottom fifty of the 2015 Human Development Index (HDI), except Equatorial Guinea, Congo, Namibia, Cabo Verde, South Africa, Gabon, Botswana, Mauritius, and Seychelles. On the other hand, three SEA countries that rank lowest in the 2015 HDI, namely Laos (141), Cambodia (143), and Myanmar (148), rank above the bottom forty. In other words, even the poorest SEA countries perform relatively better compared to the majority of SSA countries.

The next section describes the variables and highlights the hypotheses. It also presents the estimation models to empirically examine how institutional quality and natural resource dependence shape socioeconomic performance in SSA and SEA.

\section{VARIABLES, HYPOTHESES, AND MODEL SPECIFICATION}

\section{Variables}

\section{Dependent variables (Socioeconomic performance)}

As already noted, the empirical analysis of the present paper considers three socioeconomic performance measures, including (1) per capita GDP growth, (2) FDI, and (3) the infant mortality rate. First, per capita GDP growth is a well-accepted economic performance indicator in the governance or the resource curse literature (Acemoglu et al., 2014; Arezki and van der Ploeg, 2011; Lederman and Maloney, 2007; Rodrik et al., 2004). Second, the ability of a country to attract large inflows of FDI can be regarded as an indicator of development performance. FDI can create and maintain productive growth, bring together know-how and technology diffusion, employment generation, and expansion of access to infrastructure and social services in host economies (Borensztein et al, 1998; Lim, 2001). FDI can thus be thought of as a proxy for employment, technology diffusion, access to infrastructure, and so forth. ${ }^{2}$ Finally, it has been suggested that an analysis of development performance

2. For instance, it has been argued that FDI has played a leading role for major changes in economic structure of most SEA countries (Thomsen, 1999). Foreign firms have fueled export-led growth and contributed to changes in economic structures of countries like Malaysia, Indonesia, Thailand, and the Philippines. In most SSA countries, however, FDI is mostly directed to extractive industries. Whether FDI in extractive industries generates 
should also consider other variables beyond economic growth (Stigitz et al., 2009). A country can grow rapidly without making significant improvement in terms of social welfare. For instance, in a country like Equatorial Guinea the main indicators of human development such as child mortality, primary school enrolment, and fertility rates have not improved in spite of the sustained growth of per capita income over two decades (Daniele, 2011: 566).

\section{Independent variables}

\section{- Regional location}

As for regional location, the analysis introduces one binary variable that equals unity if the country is located in SSA, and equals zero if the country is located in SEA. This binary variable will be introduced to capture whether regional/geographical location, in particular SSA, has detrimental effects on socioeconomic performance.

\section{- Institutional quality}

The current paper uses data from the World Bank's WGI as they cover a larger set of countries and years than the other data bases (see Appendix A). Moreover, the analysis focuses on the Regulatory Quality (RQ) indicator, which captures perceptions of the ability of the government to formulate and implement sound policies and regulations that permit and promote private sector development. The RQ indicator is an index based on a combination of factors, including: (1) regulations and administrative requirements for starting, operating, and closing a business; (2) investment licensing requirements; (3) the extent to which the government supports uncompetitive industries through subsidies; (5) the complexity and efficiency of the tax system; (6) labor market policies; (7) the prevalence of trade barriers; (8) the strength of the banking system and legal regulations in the banking sector; and (9) the existence of a policy, legal, and institutional framework that supports the rural or agricultural sector.

Furthermore, RQ is based on data coming from various sources, including the World Bank's Country Policy and Institutional Assessments (CPIA), the Afrobarometer, the African Development Bank Country Policy and Institutional Assessments, the Asian Development Bank Country Policy and Institutional Assessments, the Business Enterprise Environment Survey, the Bertelsmann Transformation Index, the Freedom House Countries at the Crossroads, the Transparency International Global Corruption

employment, or promotes technology diffusion in SSA is beyond the scope of the current analysis. It is assumed, however, that it does. 
Barometer Survey, the Heritage Foundation Index of Economic Freedom, the Political Risk Services International Country Risk Guide, and the (IFAD) Rural Sector Performance Assessments, among others. ${ }^{3}$

That having been said, our preference for RQ as the institutional measure is motivated by the idea that the regulations and practices captured in this indicator may have a strong influence not only on FDI, but also on GDP per capita growth and social indicators. Further, and perhaps more importantly, RQ may reflect more about the overall institutional quality than what matters only to private sector development. For example, a country with a sound RQ is also likely to have a more effective and less corrupt government.

This can be illustrated by the strong correlation between the RQ scores and some selected institutional indicators (see Table 2). RQ has a 0.8 correlation with CPI, a 0.9 correlation with Governance Effectiveness, a 0.81 correlation with the Fraser Institute's Economic Freedom Index, and a 0.88 correlation with The Heritage Foundation's Economic Freedom Index. Such high correlations give added confidence in using the RQ variable. Nevertheless, robustness checks will be conducted using some of the other institutional variables.

Table 2. Correlations between RQ and some selected institutional indicators, 1996-2015

\begin{tabular}{l|c|c}
\hline Indicator & Correlation & Number of Obs. \\
\hline $\mathrm{RQ}$ & 1 & 1134 \\
\hline Corruption Perceptions Index (TI) & 0.80 & 550 \\
\hline Control of Corruption (WGI) & 1 & 1134 \\
\hline Governance Effectiveness (WGI) & 0.90 & 917 \\
\hline Economic Freedom Summary Index (Fraser Institute) & 0.81 & 615 \\
\hline Economic Freedom (The Heritage Foundation) & 0.88 & 977 \\
\hline
\end{tabular}

\section{- Dependence on natural resources}

Traditionally, dependence on natural resources has been captured by measuring the share of natural resource exports in percentage of total merchandise exports

3. Readers interested in learning how this indicator is constructed, in particular which individual variables are used to construct it, can refer to the following technical note: http://info. worldbank.org/governance/wgi/pdf/rq.pdf 
(Boschini et al., 2013), or as a share of GDP (Sachs and Warner, 1995), or per labor force (Barro, 1991); or the ratio of resource rents to GDP (Atkinson and Hamilton, 2003); or mineral reserves in US\$ (Brunnschweiler and Bulte, 2008). In the current paper, however, preference is given to natural resource exports as a share of total merchandise exports. This is because data on exports are available for the entire period extending from 1995 to 2015 and for all the 54 SSA and SEA countries considered in the present study.

\section{Control variables}

To capture the effects of the above-mentioned variables on socioeconomic performance, the paper includes five control variables, namely inflation rates, government expenditure, official development aid (ODA), population growth, and the share of urban population in percentage of total population. These variables are selected for their potential effects on per capita GDP growth, FDI, and infant mortality, and also for their policy relevance.

\section{Inflation}

Inflation can be regarded as an indicator of the overall ability of the government to manage the economy (Fischer, 1991). An economy with higher rates of inflation is unlikely to experience higher economic growth. Thus, this variable is introduced to capture the effect of macroeconomic inadequacies on per capita GDP growth as well as on FDI and infant mortality. In fact, it has been suggested that high inflation rates discourage the flow of FDI: countries with high and uncertain inflation (unstable macroeconomic conditions) are likely to receive less FDI inflows (Asiedu, 2006). Finally, inflation may affect social progress, in particular through its impact on income. By depressing income (real wage), inflation may have more detrimental effects on the poor (Easterly and Fischer, 2001), and thus may deteriorate measures of social progress such as infant mortality.

\section{Government expenditure}

Government expenditure has been suggested to have positive and statistically significant growth effects (Wu et al., 2010). These positive effects depend, however, on the composition of public expenditure (Devarajan et al 1996) or the quality of institutions (Cooray, 2009). With regard to the relationship between government expenditure and FDI, one needs to consider two lines of argument. On the one hand, there is 
empirical evidence supporting the idea that increases in government spending result in the crowding out of private investment (Bairam, 1993). This is because increased public spending requires more government borrowing in the domestic market, which in turn reduces the capital available for the private sector. On the other hand, increased public investment in areas such as physical infrastructure and education reduces the cost of private capital, which in turn increases the level of private investment (Collier et al., 2010). Therefore, following the second line of argument one can argue that increases in government spending result in larger inflows of FDI. Finally, building on the preceding argument, increased government spending may lead to more investment in health care, water supply, and sanitation. Improvements in health, water supply, and sanitation may in turn result in reduced infant mortality (Gupta et al., 2002).

\section{Population}

Population growth has been suggested to be positively and significantly associated with economic growth in developing countries (Butkiewicz and Yanikkaya, 2010). Other studies have suggested that a large growth in population can depress growth and prevent development (van der Ploeg and Poelhekke, 2008). In the case of SSA for instance, rapid population growth since the early 1970s has been argued to have depressed individual African incomes in comparison with those of other regions such as SEA or Latin America (Ndulu et al., 2008). The empirical literature on FDI, on the other hand, has often included population size as a proxy for the market size under the hypothesis that a larger domestic market is likely to attract greater FDI inflows (see, for example, Mottaleb and Kalirajan, 2010).

\section{Official Development Aid (ODA)}

ODA is thought to positively affect performance. A developing country that receives a large inflow of foreign aid is likely to experience positive economic and social outcomes, including higher growth, reduced poverty and lower infant mortality (Arndt et al., 2016). This is because aid increases investment in physical and human capital (Clemens et al., 2012). Hence, by raising the marginal productivity of capital, ODA may have a catalyzing effect on FDI (Selaya and Sunesen, 2012). In consequence, this analysis suggests that ODA is positively associated with economic growth and FDI, and negatively associated with infant mortality. 


\section{Urban population}

The size of the urban population also can potentially influence socioeconomic performance. Some studies have suggested that it positively affects growth, as populations living in cities might be more productive compared to those living in rural areas (e.g., Bertinelli and Black, 2004). Also, a larger urban population offers some potential economic gains in terms of access to a larger pool of workers, localized knowledge spillovers, and economies of scale related to infrastructure and other public services, which in turn can influence the net inflows of FDI (Guimarae et al., 2000). Finally, urbanization is suggested to have positive implications for national development (Njoh, 2003).

Table 3 presents descriptive statistics of all continuous variables, while Table 4 provides a more detailed description as well as sources of the variables used in the current analysis.

Table 3. Descriptive statistics

\begin{tabular}{l|c|c|c|c|c}
\hline Variables & $\begin{array}{c}(\mathbf{1}) \\
\mathbf{N}\end{array}$ & $\begin{array}{c}\mathbf{( 2 )} \\
\text { mean }\end{array}$ & $\begin{array}{c}\mathbf{( 3 )} \\
\mathbf{~} \mathbf{d}\end{array}$ & $\begin{array}{c}\mathbf{( 4 )} \\
\mathbf{m i n}\end{array}$ & $\begin{array}{c}\mathbf{( 5 )} \\
\mathbf{m a x}\end{array}$ \\
\hline Urban population & 1,130 & 37.07 & 15.74 & 7.211 & 87.16 \\
\hline SSA & 1,134 & 0.833 & 0.373 & 0 & 1 \\
\hline GDP per capita growth & 1,134 & 6.788 & 1.228 & 4.028 & 10.32 \\
\hline Infant mortality rate & 1,134 & 4.012 & 0.663 & 1.792 & 5.064 \\
\hline Foreign direct investment & 1,134 & 4.841 & 2.824 & -8.871 & 9.993 \\
\hline Inflation & 1,134 & 17.361 & 150.736 & -72.729 & 4146.01 \\
\hline Population growth & 1,134 & 2.138 & 1.639 & -2.586 & 5.551 \\
\hline Resource dependence (NR) & 1,134 & 0 & 30.40 & -34.80 & 64.61 \\
\hline Interaction term (SSA * NR) & 1,134 & 3.224 & 28.49 & -34.80 & 64.61 \\
\hline Institutional Quality (RQ) & 1,134 & 0 & 20.50 & -31.67 & 63.33 \\
\hline Interaction term (SSA * RQ) & 1,134 & -1.925 & 17.02 & -31.20 & 51.98 \\
\hline ODA & 1,070 & 598.6 & 819.1 & -943.2 & 11,428 \\
\hline Government expenditure & 1,102 & 24.18 & 10.74 & 2.147 & 128.3 \\
\hline Number of groups & 54 & 54 & 54 & 54 & 54 \\
\hline
\end{tabular}


Table 4. Variables and sources

\begin{tabular}{|c|c|c|}
\hline Variable & Description & Source \\
\hline $\begin{array}{l}\text { GDP per capita } \\
\text { growth }\end{array}$ & Logarithm of per capita GDP in constant 2005 prices & $\begin{array}{l}\text { World Bank: World } \\
\text { Development } \\
\text { Indicators (WDI) }\end{array}$ \\
\hline $\begin{array}{l}\text { Resource } \\
\text { dependence (NR) }\end{array}$ & 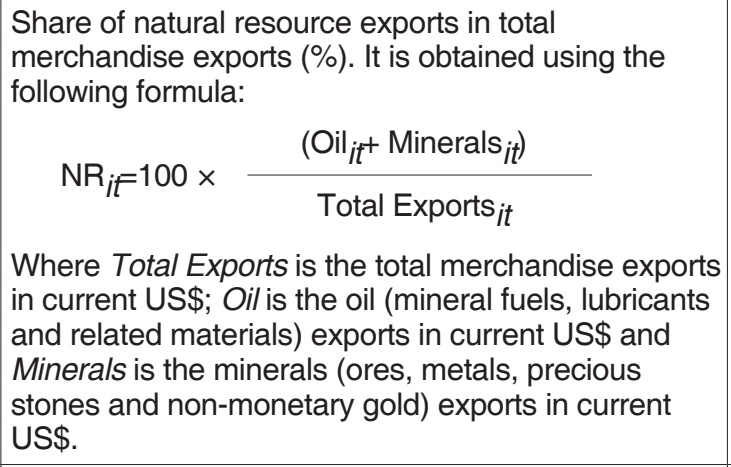 & $\begin{array}{l}\text { United Nations } \\
\text { Conference on } \\
\text { Trade and } \\
\text { Development } \\
\text { (UNCTAD) }\end{array}$ \\
\hline Regulatory Quality & $\begin{array}{l}\text { Regulatory Quality percentile rank scores, centered } \\
\text { to the mean }\end{array}$ & $\begin{array}{l}\text { Kaufman et al. } \\
\text { (2011) and available } \\
\text { online at the World } \\
\text { Bank's Worldwide } \\
\text { governance } \\
\text { indicators (WGI) }\end{array}$ \\
\hline $\begin{array}{l}\text { Government } \\
\text { expenditure }\end{array}$ & $\begin{array}{l}\text { Government Consumption Expenditure, } \\
\% \text { of GDP }\end{array}$ & WDI \\
\hline $\begin{array}{l}\text { Foreign direct } \\
\text { investment }\end{array}$ & $\begin{array}{l}\text { Logarithm of foreign direct investment inflows in } \\
\text { current US\$. Since data on FDI inflows includes both } \\
\text { positive and negative values, the log of FDI has been } \\
\text { computed as follows using Stata: -In(-FDI + 1) if FDI } \\
<=0 \text {; and In(FDI + 1) if FDI > } 0\end{array}$ & UNCTAD \\
\hline Population growth & Logarithm of total population & $\begin{array}{l}\text { International } \\
\text { Monetary Fund: } \\
\text { World Economic } \\
\text { Outlook (WEO) }\end{array}$ \\
\hline Urban population & Urban population, $\%$ of total population & UNCTAD \\
\hline ODA & $\begin{array}{l}\text { The net official development assistance and official } \\
\text { aid received in current US\$ }\end{array}$ & WDI \\
\hline $\begin{array}{l}\text { Infant mortality } \\
\text { rate }\end{array}$ & $\begin{array}{l}\text { Logarithm of the number of children dying before the } \\
\text { age of } 5 \text { per } 1,000 \text { births }\end{array}$ & WDI \\
\hline Inflation & The annual percentage of inflation. & WEO \\
\hline
\end{tabular}




\section{Hypotheses}

This section attempts to formulate the hypotheses on whether and how institutional quality and natural resource dependence shape patterns of performance in the selected economic and social indicators. For this purpose, Table 5 splits the list of 54 SSA and SEA countries into two distinct groups based on their average RQ score in the period 1995-2015. The first group consists of countries with average RQ score above zero in SSA and SEA, respectively. The second group includes countries with average RQ score below zero in SSA and SEA, respectively. Means and medians for GDP per capita, FDI inflows, and infant mortality are then computed for each of these groups based on available data for the period from 1995 to 2015. If the group with RQ scores above zero performs better than the group with RQ score below zero, then this would be suggestive evidence that good institutional quality matters in both SSA and SEA.

Table 5 shows that countries with average RQ score above zero on average have higher per capita GDP, attract larger inflows of FDI, and have lower infant mortality compared to their counterparts with average RQ scores below zero. In other words, good institutional quality matters for socioeconomic performance, irrespective of whether a country is located in SSA or SEA (Appendix B compares performance in institutional indicators between SSA and SEA countries on the one hand, and some advanced countries on the other).

Table 5. Regulatory Quality and selected economic and social indicators in SSA and SEA, average 1995-2015.

\begin{tabular}{|c|c|c|c|c|c|c|}
\hline $\begin{array}{l}\mathrm{RQ} \\
\text { score }\end{array}$ & Region & $\begin{array}{c}\text { No. of } \\
\text { countries }\end{array}$ & & $\begin{array}{c}\text { GDP per capita } \\
\text { (constant } 2005 \\
\text { US\$) }\end{array}$ & $\begin{array}{l}\text { FDI inflows, } \\
\text { million (USD) }\end{array}$ & $\begin{array}{c}\text { Mortality rate, } \\
\text { infant } \\
\text { (per } 1,000 \text { live } \\
\text { births) }\end{array}$ \\
\hline \multirow{4}{*}{$>0$} & \multirow{2}{*}{ SSA } & 4 & Mean & $5,008.08$ & $1,177.93$ & 37.54 \\
\hline & & & Median & $5,414.80$ & 392.83 & 44.32 \\
\hline & \multirow{2}{*}{ SEA } & 3 & Mean & $12,420.90$ & $4,479.06$ & 10.52 \\
\hline & & & Median & $5,685.11$ & $6,273.07$ & 7.85 \\
\hline \multirow{4}{*}{$<0$} & \multirow{2}{*}{ SSA } & 41 & Mean & $1,471.70$ & 425.03 & 75.10 \\
\hline & & & Median & 594.1 & 210.02 & 75.51 \\
\hline & \multirow{2}{*}{ SEA } & 6 & Mean & 780.07 & $2,754.34$ & 44.57 \\
\hline & & & Median & 611.18 & $1,528.91$ & 44.21 \\
\hline
\end{tabular}

Source: Author's calculations based on data from the IMF, World Economic Outlook, World Bank, WDI 
Similarly, in order to describe the relationship between natural resource dependence and socioeconomic performance in SSA and SEA, Table 6 classifies the 54 countries into two groups - resource-dependent and non-resource-dependent. The resource-dependent group comprises countries with average natural resource exports representing at least 25 percent of total merchandise exports in the period 1995-2015. In the same vein, the non-resource-dependent group consists of countries with average natural resource exports representing less than 25 percent of total merchandise exports in the period 1995-2015. ${ }^{4}$ Again, means and medians for GDP per capita, FDI inflows, and infant mortality are computed for each group based on available data for the period from 1995 to 2015. The Table shows that in SSA, countries that are resource-dependent on average have higher per capita GDP and attract larger inflows of FDI compared to countries that are less dependent on natural resources. By contrast, countries that are not dependent on natural resources on average experience lower infant mortality compared to their resource-dependent counterparts. This is suggestive evidence that in SSA, countries that are richly endowed with natural resources can grow rapidly and attract larger FDI flows without necessarily making social improvements.

Table 6. Natural resource dependence and selected economic and social indicators in SSA and SEA, average 1995-2015.

\begin{tabular}{|c|c|c|c|c|c|c|}
\hline $\begin{array}{l}\text { Natural resource } \\
\text { exports in } \\
\text { percentage of total } \\
\text { exports }\end{array}$ & Region & $\begin{array}{c}\text { No. of } \\
\text { countries. }\end{array}$ & & $\begin{array}{l}\text { GDP per capita } \\
\text { (constant } 2005 \\
\text { US\$) }\end{array}$ & $\begin{array}{l}\text { FDI inflows, } \\
\text { million (USD) }\end{array}$ & $\begin{array}{c}\text { Mortality rate, } \\
\text { infant } \\
\text { (per } 1,000 \text { live } \\
\text { births) }\end{array}$ \\
\hline \multirow{4}{*}{$>=25$ percent } & \multirow{2}{*}{ SSA } & 27 & Mean & $1,881.66$ & 706.22 & 78.52 \\
\hline & & & Median & 729.72 & 299.95 & 77.90 \\
\hline & \multirow{2}{*}{ SEA } & 1 & Mean & $28,649.46$ & 242.31 & 7.76 \\
\hline & & & Median & $28,649.46$ & 242.31 & 7.76 \\
\hline \multirow{4}{*}{$<25$ percent } & \multirow{2}{*}{ SSA } & 18 & Mean & $1,642.62$ & 170.55 & 61.63 \\
\hline & & & Median & 616.01 & 106.86 & 68.51 \\
\hline & \multirow{2}{*}{ SEA } & 8 & Mean & $1,661.70$ & $3,715.11$ & 36.40 \\
\hline & & & Median & 980.70 & $3,419.48$ & 31.10 \\
\hline
\end{tabular}

Source: Author's calculations based on data from the IMF, World Economic Outlook, World Bank, WDI

4. The literature on the resource-curse proposes different classification strategies (see, for example, Collier and Hoeffler 2009: 298; Davis 1995: 1770; Lundgren et al 2013: 4). 
Overall, the following hypotheses can be formulated: first, good institutional quality - a higher RQ score-improves socioeconomic performance, regardless of regional location. Second, natural resource dependence - natural resource exportsincreases GDP per capita and attracts FDI flow, but has no effect on social progress. Finally, a country located in SEA will experience higher per capita GDP growth, larger FDI flows, and lower infant mortality compared to a country located in SSA. The remainder of this section specifies the empirical model to test these hypotheses.

\section{Model Specification}

In order to test the formulated hypotheses, the following regression will be estimated:

$$
\mathrm{Y}_{i t}=\alpha+\beta_{1} S S A_{i}+\beta_{2} R Q i t+\beta_{3} N R_{i t}+\beta_{4}\left(S S A^{*} R Q\right)_{i t}+\beta_{5}\left(S S A^{*} N R\right)_{i t}+\beta_{6} Z_{i t}+\varepsilon_{i t}
$$

Where $i=1, \ldots, 54$ denotes the countries and $t=1995,1996,1997, \ldots, 2015$ is the year extending from 1995 to 2015. $Y_{i t}$ is an indicator of socioeconomic performance in country $i$ and year $t$; SSA is a time-invariant variable which equals unity if the country is located in SSA, and takes the value 0 if located in SEA; $R Q_{i t}$ is the Regulatory Quality Score in country $i$ in year $t ; N R_{i t}$ is the share of natural resource exports in percentage of total merchandise exports in country $i$ in year $t$. $S S A \times R Q$ is an interaction term between the SSA binary variable and the continuous measure of institutional quality (Regulatory Quality); similarly, $S S A \times R Q$ interacts the SSA dummy with the continuous resource dependence measure (NR). And $Z_{i t}$ is a vector of control variables, which includes annual rates of inflation in country $i$ and year $t$; net official development assistance and official aid (ODA) received in current US\$ per capita in country i and year t; government expenditure in percentage of GDP in country $i$ and year $t$; population growth (logarithm of total population) in country $i$ and year $t$; and the size of the urban population as a percentage of the total population in country $i$ and year $t$. Finally, $\varepsilon_{i t}$ is the error term.

Equation (1) thus allows us to see the strength of institutional quality, natural resource dependence, and their interactions with regional location in explaining socioeconomic performance across SSA and SEA. Further, it shows whether the effect on socioeconomic performance of institutional quality and resource dependence can be influenced by regional location. A brief discussion of how to interpret the coefficients of equation (1) is provided in Appendix (C).

Moreover, in order to allow for meaningful interpretation of the results, the values 
of Regulatory Quality scores $(R Q)$ as well as the share of natural resource exports in total merchandise exports (NR) are centered to their respective means. This transformation allows us to evaluate the impact of being located in SSA and SEA on Y at the mean of $R Q$ and NR, respectively. The benefit of centering is that values of zero on $R Q$ or $N R$ would correspond to the mean, whereas without centering, this would not be the case (Jaccard et al., 1990). More specifically, without centering, values of zero would correspond to zero natural resource exports and zero institutional quality. Since in the real world, every country in SSA or SEA exports some amount of natural resources and experiences some level of institutional quality, it is entirely appropriate to use centered values.

Before estimating regression (1), it is worth noting the following points. First, the panel at hand is unbalanced. As shown in Table 3, observations for some continuous variables are missing. Second, the number of countries (cross-sections) is larger than the number of years (time series), that is $N>T$. Third, countries within and across both SSA and SEA may potentially exhibit cross-sectional dependence, perhaps due to some unobservable common factors, including location, distance, or common economic or institutional factors across or within the two regions. It has been stated that many countries in both SSA and SEA have similar social structures and history, ethnic and religious diversity, and institutional landscapes dominated by authoritarian regimes, corruption, patronage, and elite rent-seeking (Lewis, 2013: 52). Also, changes in commodity prices are likely to affect economies in both regions. Overall, the presence of cross-sectional dependence in the dataset is confirmed after conducting Pesaran's test of cross sectional dependence. The null hypothesis of no contemporaneous correlation is rejected for all regressions (the p-value of Pesaran's test equals 0.000 using each of the three dependent variables). This in turn suggests that estimating regression (1) without accounting for such disturbances would lead to biased statistical inference (Hsiao 2014: 327). Finally, including fixed effects in regression (1) would remove one of the main variables of interest - SSA - which is time-invariant.

Straightforward alternatives for estimating regression (1) are pooled OLS and random effects. The former constitutes the preferred estimation strategy given our interest in examining the overall relationship between institutional quality, dependence on natural resources, and socioeconomic performance for all individual countries included in the sample. Furthermore, the interest here is in testing whether the behavioral relationship predicting socioeconomic performance from one year to the other over the twenty-one-year period is the same across SSA and SEA countries.

The aforementioned concerns, including the unbalanced nature of the panel at hand, cross-sectional dependence, time-invariant independent variables, alongside the purpose of the current analysis, justify the use of pooled OLS with Driscoll-Kraay 
standard errors. The estimators proposed by Driscoll and Kraay (1998) and adjusted by Hoechle (2007) produce heteroscedasticity consistent standard errors that are robust to temporal and spatial dependence in unbalanced panel data with $N>T$. In addition, it is worth noting that in regression (1), residuals are constrained to be autocorrelated up to 2 lags. The choice for the 2 year lags follows procedures proposed by Newey and West (1994) for automatically selecting the optimum number of lags according to an asymptotic mean squared error criterion. ${ }^{5}$

\section{RESULTS}

In Table 7, columns (1), (2), and (3) show the estimation results when the dependent variable is lnGDP (per capita GDP growth), lnFDI (growth rate of FDI inflows), and lnIMR (infant mortality rate), respectively. The results reported in Table 7 are based on values of RQ and NR centered to their respective means. Results using original data are reported in Appendix D. Overall, in spite of the small magnitudes of the coefficients, the results show a number of noticeable points:

First, column (1) suggests that all else held constant, being located in SSA is significantly correlated with negative per capita GDP growth relative to being located in SEA. Second, good institutional quality (higher RQ score) is associated with increased per capita GDP growth in both SSA and SEA. Note that the coefficients on Institutional Quality $(\mathrm{RQ})$ and the interaction term $(\mathrm{SSA} \times \mathrm{RQ})$ represent the value of the correlations for SEA and SSA, respectively. Similarly, the coefficients on NR and the interaction term (SSA*NR) indicate the magnitude and direction of the correlations for SEA and SSA, respectively. These coefficients suggest that resource dependence is not significantly associated with good performance in per capita GDP growth in both SSA and SEA. A detailed discussion on how to interpret these coefficients is provided in Appendix $\mathrm{C}$.

In column (2), results indicate that for a country located in SEA, good institutional quality is correlated with increased FDI inflows relative to a country located in SSA, all else held constant. By contrast, for a country located in SSA, higher dependence on natural resources is significantly associated with increased FDI inflows. This is shown by the coefficient on the interaction term (SSA $\times$ NR). Overall, column (2) suggests that correlations between institutional quality, natural resource dependence, and FDI inflows differ between SSA and SEA.

5. This procedure is available in Stata using the xtscc program (For more details, see, Hoechle 2007) 
In column (3), results indicate that being located in SSA is significantly associated with higher infant mortality relative to being located in SEA, all else held constant. Second, good institutional quality is significantly associated with decreased infant mortality in both SSA $(-0.018+0.009)$ and SEA (-0.018). Third, the association between dependence on natural resources and infant mortality is insignificant in both SSA and SEA.

Table 7. Estimation Results

\begin{tabular}{|c|c|c|c|}
\hline VARIABLES & $\begin{array}{c}\text { (1) } \\
Y=\text { per capita GDP }\end{array}$ & $\begin{array}{l}(2) \\
Y=F D I\end{array}$ & $\begin{array}{c}(3) \\
Y=\text { Infant Mortality }\end{array}$ \\
\hline SSA & $\begin{array}{c}-0.526^{\star * *} \\
(0.059)\end{array}$ & $\begin{array}{l}-0.725 \\
(0.532)\end{array}$ & $\begin{array}{c}0.695^{\star \star *} \\
(0.067)\end{array}$ \\
\hline Institutional Quality (RQ) & $\begin{array}{c}0.027^{\star * *} \\
(0.002)\end{array}$ & $\begin{array}{c}0.037^{* * *} \\
(0.009)\end{array}$ & $\begin{array}{c}-0.018^{* * *} \\
(0.003)\end{array}$ \\
\hline Interaction term (SSA * RQ) & $\begin{array}{c}-0.009^{\star \star \star} \\
(0.001)\end{array}$ & $\begin{array}{l}-0.0157 \\
(0.0111)\end{array}$ & $\begin{array}{c}0.009^{\star * \star} \\
(0.002)\end{array}$ \\
\hline Resource dependence (NR) & $\begin{array}{l}0.005 \\
(0.004)\end{array}$ & $\begin{array}{l}-0.0173^{*} \\
(0.00945)\end{array}$ & $\begin{array}{c}0.005 \\
(0.003)\end{array}$ \\
\hline Interaction term (SSA * NR) & $\begin{array}{c}0.003 \\
(0.005)\end{array}$ & $\begin{array}{l}0.020^{\star *} \\
(0.009)\end{array}$ & $\begin{array}{l}-0.001 \\
(0.003)\end{array}$ \\
\hline Inflation & $\begin{array}{c}0.000^{* * *} \\
(0.000)\end{array}$ & $\begin{array}{c}0.000 \\
(0.000) \\
\end{array}$ & $\begin{array}{c}0.000^{* * *} \\
(0.000)\end{array}$ \\
\hline Government expenditure & $\begin{array}{c}0.014^{\star \star *} \\
(0.002)\end{array}$ & $\begin{array}{l}0.027^{*} \\
(0.013)\end{array}$ & $\begin{array}{c}-0.009^{* * *} \\
(0.002)\end{array}$ \\
\hline ODA & $\begin{array}{l}0.000^{*} \\
(0.000)\end{array}$ & $\begin{array}{c}0.001^{* * *} \\
(0.000)\end{array}$ & $\begin{array}{c}-0.000^{\star * \star} \\
(0.000)\end{array}$ \\
\hline Population growth & $\begin{array}{c}-0.219^{* * *} \\
(0.033)\end{array}$ & $\begin{array}{c}0.436^{* * *} \\
(0.078)\end{array}$ & $\begin{array}{c}0.076^{* * *} \\
(0.010)\end{array}$ \\
\hline Urban population & $\begin{array}{c}0.028^{\star * \star} \\
(0.003)\end{array}$ & $\begin{array}{c}0.035^{\star \star \star} \\
(0.009)\end{array}$ & $\begin{array}{c}-0.012^{* * *} \\
(0.001)\end{array}$ \\
\hline Constant & $\begin{array}{c}6.290^{\star * *} \\
(0.179)\end{array}$ & $\begin{array}{l}1.983^{\star *} \\
(0.883)\end{array}$ & $\begin{array}{c}4.053^{\star \star \star} \\
(0.110)\end{array}$ \\
\hline Observations & 1,035 & 1,035 & 1,035 \\
\hline R-squared & 0.609 & 0.280 & 0.670 \\
\hline Number of groups & 54 & 54 & 54 \\
\hline
\end{tabular}

Standard errors in parentheses

*** $p<0.01,{ }^{* *} p<0.05,{ }^{*} p<0.1$ 
Additionally, the coefficients on control variables are also of interest for both SSA and SEA: (1) as one could expect, larger urban population size is significantly associated with increased per capita GDP growth ([]0.028) and FDI inflows (0.035), and reduced infant mortality $(-0.012)$; (2) larger government expenditure is significantly associated with increased per capita GDP growth (0.014) and FDI inflows (0.027), and reduced infant mortality (-0.009); (3) in spite of the small coefficients, ODA is significantly correlated with increased per capita GDP and FDI inflows, and reduced infant mortality; and (4) higher population growth is significantly correlated with reduced per capita GDP growth (-0.219), increased FDI inflows ${ }^{6}$; and decreased infant mortality. ${ }^{7}$

\section{SUMMARY AND IMPLICATIONS}

Understanding SSA development problems will often require explaining whether, why, and how economic and social variables in SSA respond differently to physical, institutional, or political forces compared to other developing regions. This paper contributed to such an exercise and added to the recent increasing research interest focusing on development processes and outcomes in SSA and SEA. Focusing on the period from 1995 to 2015, the paper explored the relationship between institutional quality, dependence on natural resource endowments, and performance in three economic and social indicators: (1) per capita GDP growth; (2) FDI; and (3) infant mortality rate. In order to investigate these relationships, the paper used Pooled OLS with robust estimators controlling for temporal and spatial dependence.

The paper showed that the overall socioeconomic performance in SEA is better compared to SSA. Further, in SSA, good institutional quality-higher regulatory quality score - is significantly associated with increased per capita GDP growth and decreased infant mortality, while dependence on natural resources is only significantly associated with increased FDI. In SEA, by contrast, good institutional quality is significantly associated with increased per capita GDP growth and FDI inflows, and decreased infant mortality. Additionally, none of the three performance measures is

6. This is consistent with the theory on the determinants of FDI, according to which higher population growth (a proxy for market size) is associated with higher FDI inflows.

7. This correlation may, however, appear counter-intuitive. A recent study shows that reduced mortality leads to population growth (Shelton 2014). Furthermore, the study argues that reduced child mortality contributes to rapid population growth in particular in pre-transition societies such as in SSA. It seems thus possible that population growth at some time lag could be negatively correlated with infant mortality. 
significantly associated with higher dependence on natural resources in SEA.

While existing research highlights similarities between SSA and SEA in terms of their institutional landscape - populated by corrupt and non-democratic governments - the present paper attempted to establish correlations between institutional quality and good development outcomes in the two regions. The paper also showed that between 1995 and 2015, higher levels of natural resource exports in SSA only attracted FDI flows without improving people's income or social welfare.

Finally, it is recognized that countries in SSA and other developing regions tend to share similarities in terms of their measured levels of institutional quality-i.e., level of corruption, economic freedom, governance. Yet, SSA faces greater development challenges compared to the rest of the developing world (e.g., SEA). In this regard, further empirical work is needed to figure out how developing countries (or regions) displaying similarities in institutional quality can experience diverging development performance. Indeed, there is the possibility that countries may in fact differ in terms of the rules and practices considered to construct institutional indicators. Transparency International's CPI, for example, considers several dimensions of corruption such as corruption among public officials, diversion of public funds, irregular payments in public contracts, level of corruption between administrations and local businesses or foreign companies, anti-corruption policy, and so forth. Similarly, the World Bank's Regulatory Quality indicator is constructed based on a combination of regulatory dimensions, including (1) regulations and administrative requirements for starting, operating, and closing a business; (2) investment licensing requirements; (3) the extent to which the government supports uncompetitive industries through subsidies; (5) the complexity and efficiency of the tax system; (6) labor market policies; (7) prevalence of trade barriers; (8) strength of the banking system and legal regulations in the banking sector; and (9) the existence of a policy, legal, and institutional framework that supports the rural or agricultural sector. It may thus be argued that cross-country variations in these dimensions may in turn influence the differential development outcomes across countries.

For example, Andrews (2010), compares public financial management practices across countries labeled as reflecting good governance in the World Bank's good governance indicator. He finds that these countries have varying governance structures in terms of fiscal rules, budget transparency and accountability arrangements, and performance management as well as the use of modern financial management practices. Thus, rephrasing Rockman and Hahm (2011: 14), "there is no single right answer to the question of what constitute good or bad governance (institutional quality), since the concept itself is multidimensional, conditional, and consequential".

One way to gain leverage over the issue of institutional quality and development 
in SSA and SEA would be to address the question of how rules and practices for fighting corruption, or for hiring and firing civil servants, affect economic and social outcomes across the two regions. Such analysis would facilitate institutional reforms in SSA countries by identifying particular practices and rules that matter for development.

\section{REFERENCES}

Acemoglu, D., Johnson, S. \& Robinson, J.A. 2005. Chapter 6 Institutions as a Fundamental Cause of Long-Run Growth. Handbook of Economic Growth 1 (PART A): 385-472.

Acemoglu, D., Naidu, S., Restrepo, P., \& Robinson, J.A. 2014. Democracy Does Cause Growth. NBER Working Paper Series (20004).

Arezki, R., \& van der Ploeg, F. 2011. Do Natural Resources Depress Income per Capita? Review of Development Economics, 15(3): 504-21.

Andrews, M. 2010. Good Government Means Different Things in Different Countries. Governance, 23(1): 7-35.

Arndt, C., Jones, S., \& Finn Tarp. 2016. Assessing Foreign Aid's Long Run Contribution to Growth and Development. World Development, 69: 6-18.

Asiedu, E. 2006. Foreign direct investment in Africa: the role of government policy, institutions and political instability. World Economy, 29(1): 63-77.

Bairam, I N. 1993. The Externality Effect of Government Expenditure on Investment in OECD Countries. Applied Economics, 25(7): 1-716.

Berendsen, B.., Dietz, T., Nordholt, H.S., \& van der Veen, R. 2013. Asian Tigers, African Lions: Comparing the Development Performance of Southeast Asia and Africa. Brill. London.

Bertinelli, L., \& Duncan, B. 2004. Urbanization and growth. Journal of Urban Economics, 56(1): 80-96.

Booth, D. 2012. Development as a Collection Action Problem: Addressing the Real Challenges of African Governance. London.

Borensztein, E., De Gregorio J., \& Lee J-W. 1998. How Does Foreign Direct Investment Affect Economic Growth? Journal of International Economics, 45: 115135.

Boschini, A., Pettersson, J. \& Roine, J. 2013. The Resource Curse and Its Potential Reversal. World Development, 43: 19-41.

Brambor, T., Clark, W.R., \& Golder, M. 2005. Understanding Interaction Models: 
Improving Empirical Analyses. Political Analysis, 14: 63-82.

Brunnschweiler, C. N. 2008. Cursing the Blessings? Natural Resource Abundance, Institutions, and Economic Growth. World Development, 36(3): 399-419.

Butkiewicz, J. L., \& Yanikkaya. 2010. Minerals, Institutions, Openness, and Growth: An Empirical Analysis. Land Economics, 86(2): 313-328.

Clemens, M. A., Steven, R., Bhavnani, R.R., \& Bazzi, S. 2012. Counting Chickens When They Hatch: Timing and the Effects of Aid on Growth. The Economic Journal, 122(561): 590-617.

Collier, P., \& Gunning, J. 1999. Explaining African Economic Performance. Journal of Economic Literature, 37(1): 64-111.

Collier, P., \& Hoeffler, A. 2009. Testing the Neocon Agenda: Democracy in ResourceRich Societies. European Economic Review, 53(3): 293-308.

Collier, P., van der Ploeg, R., Spence, M., \& Venables, A.J. 2010. Managing Resource Revenues in Developing Economies. IMF Staff Papers 57: 84-118.

Cooray, A. 2009. Government Expenditure, Governance and Economic Growth. Comparative Economic Studies, 51(3): 401-18.

Daniele, V. 2011. Natural Resources \& the 'Quality' of Economic Development. Journal of Development Studies, 47(4): 545-73.

Davis, G.A. 1995. Learning to Love the Dutch Disease: Evidence from the Mineral Economies. World Development, 23(10): 1765-79.

Devarajan, S., Swaroop, V., \& Heng-Fu Zou. 1996. The Composition of Public Expenditure and Economic Growth. Journal of Monetary Economics, 37(1996): 313-44.

Driscoll, J. C., \& Kraay, A.C. 1998. Consistent Covariance Matrix Estimation with Spatially Dependent Panel Data. Review of Economics and Statistics, 80(4): 549-60.

Easterly, W., \& Fischer, S. 2001. Inflation and the Poor. Journal of Money, Credit and Banking, 33(2): 160-78.

Fischer, Stanley. 1991. Growth, Macroeconomics, and Development. NBER macroeconomics annual, 6: 329-64.

Gallup, J.L., Sachs, J.D., \& Mellinger, A.D. 1999. Geography and Economic Development. International Regional Science Review, 22(2): 179-232.

Guimarae, P., Figueiredó, O., \& Woodward, D. 2000. Agglomeration and the Location of Foreign Direct Investment in Portugal. Journal of Urban Economics, 47(1): 115-35.

Gupta, S., Verhoeven, M., \& Erwin R Tiongson. 2002. The Effectiveness of Government Spending on Education and Health Care in Developing and Transition Economies. European Journal of Political Economy, 18: 717-37.

Henley, D. 2012. The Agrarian Roots of Industrial Growth: Rural Development in 
South-East Asia and Sub-Saharan Africa. Development Policy Review, 30: S2547.

Henley, D. 2015. Asia-Africa Development Divergence: A Question of Intent. London: Zed Books.

Hoechle, D. 2007. Robust Standard Errors for Panel Regressions with Cross-Sectional Dependence. Stata Journal, 7(3): 281-312.

Hsiao, C. 2014. Analysis of Panel Data. Cambridge University Press.

Jaccard, J., Wan, C.K., \& Turrisi, R. 1990. The detection and interpretation of interaction effects between continuous variables in multiple regression. Multivariate behavioral research, 25(4): 467-478.

Kunčič, A. 2014. Institutional Quality Dataset. Journal of Institutional Economics 10(1): 135-61.

Kaufmann, D., Kraay, A., \& Mastruzzi, M. 2011. The Worldwide Governance Indicators: Methodology and Analytical Issues. Hague Journal on the Rule of Law, 3(2): 220-46.

Kelsall, T. 2013. Economic Growth and Political Succession: A Study of Two Regions. London: Developmental Regimes in Africa Project.

Lederman, D. \& Maloney, W. 2007. Natural Resources: Neither Curse nor Destiny. Washington, DC.: Stanford University Press.

Lewis, P. 2013. Cross-regional comparisons in development: questions, approaches, and challenges. In Asian Tigers, African Lions: Comparing the Development Performance of Southeast Asia and Africa. Berendsen, B. et al. (Eds). Brill. London.

Lim, E. 2001. Determinants of, and the relation between, foreign direct investment and growth: a summary of the recent literature. International Monetary Fund, Middle Eastern Department, Working Paper 01/175.

Lundgren, C., Alun, T., \& York, R. 2013. Boom, Bust, or Prosperity?: Managing Sub-Saharan Africa's Natural Resource Wealth. Washington, DC: International Monetary Fund.

Mottaleb, K.A. \& Kalirajan, K. 2010. Determinants of foreign direct investment in developing countries: a comparative analysis. The Journal of Applied Economic Research, 4(4): 369-404.

Ndulu, B.J, O’Connell, S.A, Bates, R., \& Collier, P. 2008. The Political Economy of Economic Growth in Africa 1960-2000. Vol. 1. Cambridge: Cambridge University Press.

Newey, W.K, \& West, K.D. 1994. Automatic Lag Selection in Covariance Matrix Estimation. Review of Economic Studies, 61: 631-53.

Njoh, A.J. 2003. Urbanization and Development in Sub-Saharan Africa. Cities, 20(3): 
167-74.

Rockman, B.A., \& Hahm, S.D. 2011. The Notion of Good and Bad Governance in Comparative Perspective. The Korean Journal of Policy Studies, 26(2): 1-16.

Rodrik, D., Subramanian, A.,\& Trebbi, F. 2004. Institutions Rule: The Primacy of Institutions over Geography and Integration in Economic Development. Journal of Economic Growth, 9(2): 131-65.

Sachs, J.D., \& Warner, A.M. 1995. Economic Convergence and Economic Policies. NBER Working Paper Series 47.

Selaya, P., \& Sunesen, E.R. 2012. Does Foreign Aid Increase Foreign Direct Investment? World Development, 40(11): 2155-76.

Shelton, J.D. 2014. Taking Exception. Reduced Mortality Leads to Population Growth: An Inconvenient Truth. Global health, science and practice, 2(2): 135-38.

Stigitz, J.E., Sen, A., \& Fitoussi, J.P. 2009. Report by the Commission on the Measurement of Economic Performance and Social Progress. www.stiglitz-sen-fitoussi. fr (January 26, 2017).

Thomsen, S. 1999. Southeast Asia: The Role of Foreign Direct Investment Policies in Development. OECD Working Papers. http://dx.doi.org/10.1787/431857742281 (February 1, 2017).

UNDP (United Nations Development Program). 2015. Human development Report. Geneva.

van der Ploeg, F., \& Poelhekke, S. 2009. Volatility and the Natural Resource Curse. Oxford Economic Papers, 61(4): 727-760.

van Donge, K., Henley, D., \& Lewis, P. 2012. Tracking Development in Southeast Asia and Sub-Saharan Africa; The Primacy of Policy. Development Policy Review, 30(1): 5-24.

Wu, S.Y., Tang, J.H., \& Lin, S. 2010. The Impact of Government Expenditure on Economic Growth: How Sensitive to the Level of Development? Journal of Policy Modeling, 32: 804-17. 


\section{Appendix A. Institutional indicators by category}

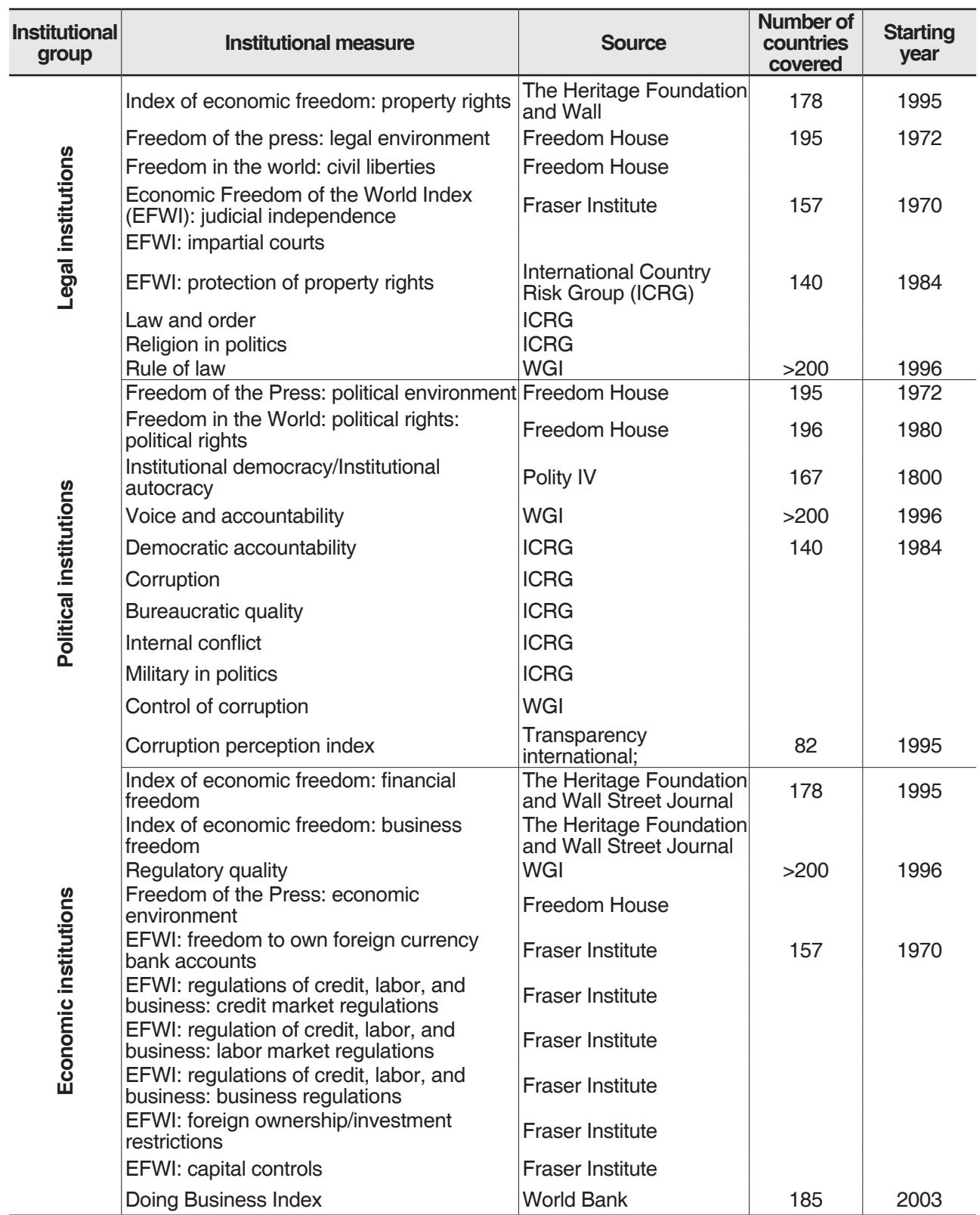

Source: as noted in table; and adapted from Kunčič (2014: 143)

Note: The Table, adapted from Kunčič (2014: 143), classifies various institutional composite indicators into legal, economic, and political institutions. The table shows that that time and country coverage vary widely across different sources, with the largest coverage provided by the WGI. 


\section{Appendix B. Comparison of institutional indicators between SSA, SEA, and more advanced economies}

\section{Corruption Perception Index scores}

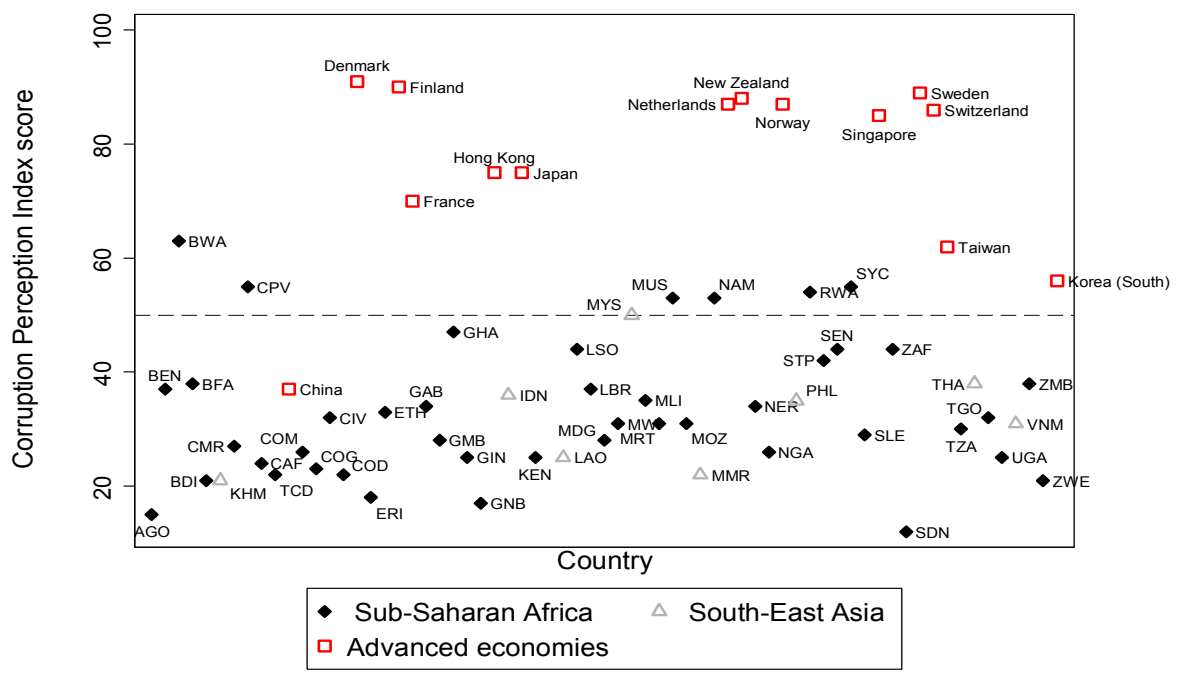

Source: Transparency International, Corruption Perception Index 2015

Regulatory Quality scores, $2015(-2.5$ to +2.5$)$

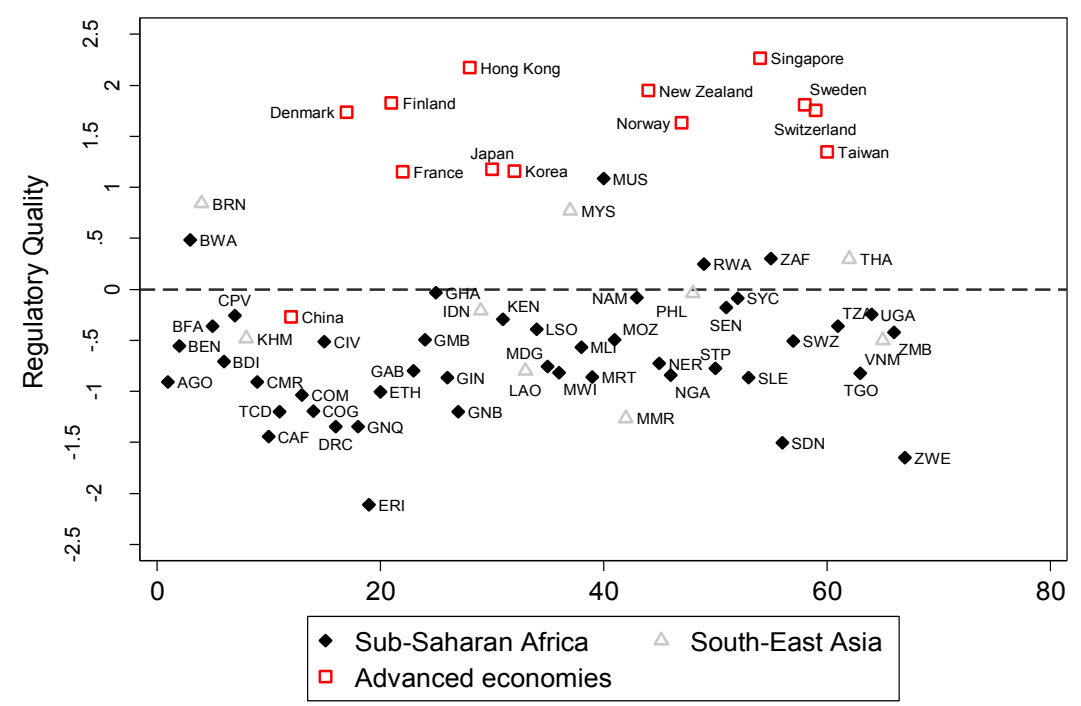

Source: World Bank, World Governance Indicators (WGI) 


\section{Appendix C. Interpreting Coefficients of Regression (1)}

In regression (1), $\alpha$ (the intercept) is the expected effect of being located in SEA relative to being located in SSA, holding constant institutional quality and dependence on natural resources. $\beta_{1}$ captures the effects of being located in SSA relative to being located in SEA, holding constant institutional quality and dependence on natural resources. This is because $\mathrm{SSA}=1$ if the country is located in SSA, and SSA $=0$ if the country is located in SEA (for more on the interpretation of interaction models, see, Brambor et al., 2005; Jaccard et al., 1990).

Additionally, the coefficients on $R Q$ and $N R$ capture respectively the effects of RQ and NR on Y when $S S A=0$, that is, for a SEA country. By contrast, the coefficients on the two interaction terms capture the effects of $R Q$ and $N R$ on $Y$ when $S S A=1$, that is, for a SSA country. Specifically, because SSA is dichotomous, and equals either 0 or 1 , the marginal effect of $R Q$ for a SEA country, that is, when SSA equals 0 is given by $\frac{\partial \mathrm{Y}}{\partial \mathrm{RQ}}=\beta_{2}$. This is because $\beta_{2}\left[=\beta_{2}+\left(\beta_{4} * 0\right)\right]$. Similarly, the marginal effect of RQ for a SSA country, that is, when SSA equals unity, is given by $\frac{\partial \mathrm{Y}}{\partial \mathrm{RQ}}=\beta_{2}+\beta_{4}$. This is because $\beta_{2}+\beta_{4}\left[=\beta_{2}+\left(\beta_{4} * 1\right)\right]$.

So, it can be said that for a SEA country, an increase of 1 unit of $R Q$ will lead to a $\beta_{2}$ change in $Y$, holding constant other variables. Similarly, for a SSA country, a 1 -unit increase in $R Q$ will change $\mathrm{Y}$ by $\beta_{2}+\beta_{4}$, holding the other variables constant.

The same logic applies for computing the marginal effect of natural resource dependence on Y for SSA and SEA countries. Hence, the marginal effect of $N R$ on $Y$ for a SEA country $(\mathrm{SSA}=0)$ is simply $\beta_{3}$. This is because $\beta_{3}\left[=\beta_{3}+\left(\beta_{5} * 0\right)\right]$. Similarly, the marginal effect of $N R$ on $Y$ for a SSA country $(\mathrm{SSA}=1)$ is $\beta_{3}+\beta_{5}$, because $\beta_{3}+\beta_{5}$ $\left[=\beta_{3}+\left(\beta_{5} * 1\right)\right]$.

In consequence, a 1-unit increase in natural resource dependence (natural resource exports) in a SEA country will lead to a $\beta_{3}$ change in Y. In a SSA country, by contrast, a 1-unit increase in natural resource dependence will change $\mathrm{Y}$ by $\beta_{3}+\beta_{5}$. 
Appendix D. Estimation results using original data for RQ and NR

\begin{tabular}{|c|c|c|c|}
\hline VARIABLES & $\begin{array}{c}(1) \\
Y=\text { per capita GDP }\end{array}$ & $\begin{array}{c}(2) \\
Y=F D I\end{array}$ & $\begin{array}{c}(3) \\
Y=\text { Infant Mortality }\end{array}$ \\
\hline SSA & $\begin{array}{l}-0.333 \\
(0.207)\end{array}$ & $\begin{array}{l}-0.936 \\
(0.603)\end{array}$ & $\begin{array}{l}0.416^{\star * *} \\
(0.066)\end{array}$ \\
\hline Institutional Quality (RQ) & $\begin{array}{c}0.027^{\star \star \star} \\
(0.002)\end{array}$ & $\begin{array}{c}0.037^{\star \star \star} \\
(0.009)\end{array}$ & $\begin{array}{l}-0.018^{\star \star \star} \\
(0.003)\end{array}$ \\
\hline Interaction term (SSA * RQ) & $\begin{array}{c}-0.009^{\star * *} \\
(0.001)\end{array}$ & $\begin{array}{l}-0.016 \\
(0.011)\end{array}$ & $\begin{array}{c}0.009^{* * *} \\
(0.002)\end{array}$ \\
\hline Resource dependence (NR) & $\begin{array}{l}0.005 \\
(0.004)\end{array}$ & $\begin{array}{l}-0.017^{\star} \\
(0.009)\end{array}$ & $\begin{array}{c}0.005 \\
(0.003)\end{array}$ \\
\hline Interaction term (SSA * NR) & $\begin{array}{c}0.003 \\
(0.005)\end{array}$ & $\begin{array}{l}0.020^{* *} \\
(0.009)\end{array}$ & $\begin{array}{l}-0.001 \\
(0.003)\end{array}$ \\
\hline Inflation & $\begin{array}{l}0.000^{\star \star *} \\
(0.000)\end{array}$ & $\begin{array}{c}0.000 \\
(0.000)\end{array}$ & $\begin{array}{l}0.000^{\star * *} \\
(0.000)\end{array}$ \\
\hline Government expenditure & $\begin{array}{l}0.014^{\star * *} \\
(0.002)\end{array}$ & $\begin{array}{l}0.027^{*} \\
(0.013)\end{array}$ & $\begin{array}{c}-0.009^{* * *} \\
(0.002)\end{array}$ \\
\hline ODA & $\begin{array}{l}0.000^{*} \\
(0.000)\end{array}$ & $\begin{array}{c}0.001^{* \star *} \\
(0.000)\end{array}$ & $\begin{array}{c}-0.000^{\star \star \star} \\
(0.000)\end{array}$ \\
\hline Population growth & $\begin{array}{c}-0.219^{\star \star *} \\
(0.033)\end{array}$ & $\begin{array}{c}0.436^{\star \star *} \\
(0.078)\end{array}$ & $\begin{array}{c}0.0763^{\star \star \star} \\
(0.0103)\end{array}$ \\
\hline Urban population & $\begin{array}{l}0.028^{\star \star *} \\
(0.003)\end{array}$ & $\begin{array}{c}0.035^{\star * *} \\
(0.009)\end{array}$ & $\begin{array}{l}-0.012^{* * *} \\
(0.001)\end{array}$ \\
\hline Constant & $\begin{array}{l}5.262^{\star * *} \\
(0.259)\end{array}$ & $\begin{array}{l}1.409^{*} \\
(0.767)\end{array}$ & $\begin{array}{l}4.452^{* * *} \\
(0.127)\end{array}$ \\
\hline Observations & 1,035 & 1,035 & 1,035 \\
\hline R-squared & 0.609 & 0.280 & 0.670 \\
\hline Number of groups & 54 & 54 & 54 \\
\hline
\end{tabular}

Standard errors in parentheses

*** $p<0.01,{ }^{* *} p<0.05,{ }^{*} p<0.1$ 